\title{
КРИТИКА
}

И БИБЛИОГРАФИЯ

Куракин А.В., Костенников М.В.

\section{НОВАЯ КНИГА О ГОСУДАРСТВЕННОЙ ГРАЖДАНСКОЙ СЛУЖБЕ РЕЦЕНЗИЯ НА УЧЕБНЫЙ КУРС А.А. ГРИШКОВЦА ПО ТЕМЕ: «ГОСУДАРСТВЕННАЯ ГРАЖДАНСКАЯ СЛУЖБА». - М.: ДЕЛО И СЕРВИС, 2014. - 624 С.}

\begin{abstract}
Аннотация: В рецензии отмечается, что проблеме государственной службы вообще и государственной гражданской службе в частности посвящено достаточно много работ самого различного характера: это и учебники, учебные пособия, монографии и диссертации. В опубликованных научных работах, а также учебных курсах рассматриваются самые различные аспекты государственно-служебных отношений, кроме того, институт государственной службы изучается представителями самых разных направлений научного значения. Однако, несмотря на междисииплинарный подход в исследовании государственно-служебных отношений, институт государственной службы все же наиболее подробно исследован в науке административного права. Методологическую основу работы составили современные достижения теории познания. В процессе исследования применялись общефилософский, теоретический, эмпирический методы (диалектика, системный метод, анализ, синтез, аналогия, дедукция, наблюдение, моделирование), традиционноправовые методы (формально-логический), методы, используемые в конкретно-социологических исследованиях (статистические, экспертные оченки и др.). Проблеме государственной службы вообще и государственной гражданской службе в частности, посвящено достаточно много работ самого различного характера - это и учебники и учебные пособия, монографии, а также диссертации и т.д. В опубликованных, перечисленных научных работах, а также учебных курсах рассматриваются самые различные аспекты государственно-служебных отношений. Кроме того, институт государственной службы изучается представителями самых разных научных направлений. Однако, несмотря на междисциплинарный подход в исследовании государственно-служебных отношений, институт государственной службы все же наиболее подробно исследован в науке административного права. Ученые-административисты считают государственную службу ключевой темой и как учебного курса административного.
\end{abstract}

Ключевые слова: служба, служащий, чиновник, рецензия, реформа, эффрективность, система, успех, коррупция, регулирование.

П роблеме государственной службы вообще и государственной гражданской службе в частности, посвящено достаточно много работ самого различного характера - это и учебники и учебные пособия, монографии, а также диссертации и т.д. В опубликованных, перечисленных научных работах, а также учебных курсах рассматриваются самые различные аспекты государственно-служебных отношений. Кроме того, институт государственной службы изучается представителями самых разных научных направлений. Однако, несмотря на междисциплинарный подход в исследовании государственно-служебных отношений, институт государственной службы все же наиболее подробно исследован в науке административного права. Ученые-административисты считают государственную службу ключевой темой и как учебного курса административ-

Рецензия подготовлена при информационной поддержки компании «Консультант Плюс». 
ного права, и как одного из основных предметом для научного изучения.

Именно с позиций науки административного права профессор А.А. Гришковец подготовил рецензируемую научную работу, которая хоть и называется учебным курсом, все-таки, исходя из своего содержания, является достаточно обстоятельной монографией, в которой с точки зрения науки, а также правоприменительной практики рассматриваются наиболее актуальные вопросы института государственной гражданской службы.

Говоря об авторе представленного научного труда, необходимо отметить, что А.А. Гришковец является, пожалуй, самым известным специалистом в сфере исследования служебных отношений на государственной гражданской службе. Автор соединил в себе, по сути, уникальные качества ученого и чиновника, который на протяжении практически всей своей жизни работал на различных должностях государственной гражданской службы в федеральных органах государственной власти, одновременно проводя серьезную научную работу. Имея различный опыт государственно-служебной деятельности, автор рецензируемой монографии с успехом, уже на протяжении не одного десятка лет реализует его в своих научных трудах, а также в педагогической деятельности.

Исходя из этого, выбор темы монографии не случаен. В настоящей работе доктор юридических наук, профессор А.А. Гришковец продолжил и углубил свои научные изыскания в исследовании института государственной гражданской службы, которые он начал еще в середине 90-х годов XX в.

Именно в этот период под руководством профессора К.С. Бельского, А.А. Гришковцом была защищена кандидатская диссертация по теме: «Право государственного служащего на продвижение по службе» (1997). После защиты кандидатской диссертации наступает, пожалуй, самый содержательный период в научной деятельности Гришковца, который продолжается до 2004 г. В этот период автором публикуется целая серия научных статей и иных работ, которые посвящены малоизученным аспектам государственно-служебных отношений. Научные исследования Гришковца совпали с основными периодами реформирования государственной службы и самым непосредственным образом пересекались со знаковыми этапами развития российского законодательства о государственной службе.

Так, научные изыскания ученого исследования проходили параллельно с принятием закона
«Об основах государственной службы Российской Федерации» (1995), а также закона «О государственной гражданской службе Российской Федерации» (2004). Знаковым событием в исследовании государственной гражданской службы стала защита А.А. Гришковцом в 2004 г. в Институте государства и права Российской академии наук докторской диссертации по теме: «Проблемы правового регулирования и организации государственной гражданской службы в Российской Федерации». Защита докторской диссертации сразу выдвинула Гришковца в число самых известных специалистов в области исследования государственной гражданской службы, а также способствовала развитию науки административного права в соответствующем направлении.

Спустя десять лет А.А. Гришковец подготовил, по сути, совершенно новое исследование, которое посвящено государственной гражданской службе. В представленной работе, с позиций сегодняшнего дня, дана критическая оценка реформе государственной службы, весьма содержательно оценен ряд революционных, для данного времени предложений, относительно формирования в науке административного права, такого направления, как «Служебное право». Кроме этого, в работе дан критический анализ целому ряду исследований по предмету государственной гражданской службы, и, что самое главное, в монографии выявлен целый ряд правовых и организационных проблем, касающихся реализации законодательства о государственной гражданской службе нашей страны.

Прочтение книги дает возможность высказать ряд суждений по соответствующему предмету. Так, структурно монография состоит из предисловия, пяти глав, включающих семнадцать параграфов, заключения и списка использованных источников. Достаточно оригинальным выглядит предисловие книги - оно посвящено этапам реформы государственной службы, которые охватывают различные периоды нашей новейшей истории, но особенно интересно и смело выглядит анализ периода реформ, который касается самого современного этапа государственного строительства, а именно - периода реформ государственной службы с 2000 по 2013 гг.

Автор, в своей книге смело вскрывает недостатки реформы, ставит весьма неудобные для нынешней политической власти вопросы относительно качества и последовательности реформы государственной службы вообще и государственной гражданской службы, в частности. Предисловие книги 
как бы задает ей тон и настраивает читателя на то, что книга посвящена действительно актуальным проблемам современной государственной гражданской службы Российской Федерации.

Обращает на себя внимание тот факт, что автор монографии не увлекается цитированием научных «авторитетов», а напротив, весьма критически оценив предложения и суждения ряда авторов относительно совершенствования законодательства о государственной гражданской службе, точки, зрения которых приводятся в настоящей работе. Такой подход автора имеет под собой весьма существенные основания: во-первых, какие-то из цитируемых положений отвергнуты автором, поскольку сделанные в свое время предложения не нашли своего подтверждения на практики, даже спустя весьма длительное время с момента заявлении о них. Во-вторых, какие-то из цитируемых предложений были выдвинуты в юридической науке без должной теоретической аргументации, тем самым они также не были востребовании ни теорией, ни практикой, а ряд предложений, которые цитируются автором, просто были не верны по своей сути.

Автор работы достаточно смело, однако, соблюдая при этом научную этику, критикует заявления и предложения, которые содержаться как в научной литературе, так и в официальных документах ряда государственных деятелей, которые, в частности, проводили реформу государственной службы. Особо интересна критика политических руководителей, допустивших весьма серьезные ошибки, ставшие впоследствии на пути развития государственной службы Российской Федерации. По сути, эти структурные ошибочные решения, в определенной степени не позволяют и в настоящее время реализовать заложенный в идеи реформы государственной службы ее позитивный потенциал.

Исходя из этого, можно сделать вывод о том, что государственная служба после целого ряда структурных реформ, к сожалению не стала тем местом, где честный, способный и подготовленный молодой человек может реализовать себя в полной мере, а также принести пользу государству и обществу, сделав при этом добросовестную и честную карьеру. Применительно к предмету исследования, представляется возможным сказать, что государственная гражданская служба по-прежнему остается тем местом, где служебная карьера строиться зачастую на блате, личных родительских связях, а также деньгах. В современный период, как верно отмечает и сам автор, чиновничья карьера может также строиться и на сексуальных связях часто «нетрадиционного» характера. К сожалению, все вышеперечисленное дает возможность констатировать, что таков в сухом остатке, по сути, итог структурных и законодательных преобразований государственной службы вообще, и государственной гражданской службы в частности, за десять лет, прошедших с момента их начала.

Чтение некоторых параграфов книги может сформировать весьма «обманчивое» впечатление о том, что автор книги является романтиком, идеалистом (в хорошем смысле слова) государственной гражданской службы, позитивно оценивающим законодательство и государственно-служебные институты только за то, что они просто впервые были закреплены в российском законодательстве. Однако содержание, в частности, параграфа 2.3. Главы 2 «Замещение должности гражданкой службы» все ставит на свои места.

Автор вполне адекватно и справедливо оценивает возможности замещения руководящих должностей в системе государственной службы, тем самым отвечая на многие вопросы, а именно - почему государственная служба вообще и государственная гражданская служба, в частности, не является сегодня эффективным институтом в системе государственного управления. Почему в системе государственной службы имеет место неслыханная по объему и формам своего проявления коррупция, почему должным образом не работают конкурсные процедуры и процедуры ротации и др. Как уже отмечалось, в книге очень много интересных примеров о том, кто и почему замещает те или иные должности в системе государственной гражданской службы. Автор обращает внимание на то, как реализуются предписания законодательства относительно государственных наград и поощрений, как реализуются стимулирующие средства служебной деятельности чиновника и др. Практически во всей книги автор использует метод сравнительного правоведения, что делает работу еще более интересной, позволяет сравнивать опыт зарубежных стран с российской действительностью, причем такое сравнение делается не формально, а действительно выглядит уместным и своевременным. Автор также использует и метод исторического анализа, который позволяет сопоставить те предписания, которые имели место ранее, а именно до 1917 г. в советский период, сопоставляя их с нынешними положениями действующего законодательства о государственной гражданской службе. 
Несмотря на то, что в книге нет специального параграфа, посвященного проблеме противодействия коррупции, тем не менее, на протяжении всей книги об этом вопросе упоминается как прямо, так и косвенно. Данный подход обусловлен целым рядом обстоятельств и, прежде всего тем, что уровень коррупции, как уже поминалось в рецензии, в системе государственной службы крайне высок. В этой связи автор рассматривает целый ряд административно-правовых средств противодействия коррупции, увязывая их с организацией служебных отношений, а также со служебными процедурами, что делает их весьма органично встроенными как в институт государственной гражданской службы в целом, так и в статус государственного гражданского служащего, в частности.

Необходимо отметить, что работа написана на высоком теоретическом и научном уровне, автор также использует большое количеством различного рода цитат мыслителей, философов, писателей, делая книгу очень интересной, а также доказывает обоснованность выводов и суждений, имеющих место по ходу исследования. Стиль написания книги временами носит литературно-художественный характер, что делает ее понятной для читателя, не имеющего юридического образования или не знакомого с практикой регулиро- вания и организации государственно-служебных отношений. Следует также отметить наличие в книге большого количества предложений, направленных на улучшение качества правового регулирования самых различных аспектов служебных отношений.

Книга имеет большое количество достоинств, которые позволяют ее рекомендовать ее для использования в качестве учебного пособия в ходе повышения квалификации государственных служащих, книгу также можно рекомендовать для использования в учебном процессе, а также научноисследовательской деятельности.

Ряд замечаний, которые можно сделать по итогам прочтения книги, скорее могут носить характер придирок, в книге нет ни одного проходного или формального параграфа. Исходя из этого, авторы рецензии не считают уместным заострять внимание на каких-то мелких неточностях или спорных положениях. Автор рассматриваемого произведения зрел, самостоятелен, в связи, с чем имеет право на собственную точку зрения, особенно в том предмете, в котором разбирается весьма квалифицированно.

Поэтому, можно только поздравить доктора юридических наук, профессора Алексея Алексеевича Гришковца с его творческим, а также научным успехом.

\section{Библиография:}

1. Костенников М.В., Куракин А.В. Актуальные проблемы администра-тивного права. - М., 2013.

2. Куракин А.В. Предмет административно-правового регулирования в механизме противодействия коррупции в полиции. - Домодедово: ВИПК МВД России, 2013.

3. Куракин А.В. Международное и административное право и противодействие коррупции в системе государственной гражданской службы // NB: Административное право и практика администрирования. - 2014. - 1. - C. 53 - 81. DOI: 10.7256/2306-9945.2014.1.11051. URL: http://www.e-notabene.ru/ al/article_11051.html

4. Куракин А.В., Костенников М.В. Административно-правовое противодействие коррупции в системе государственной службы и в деятельности сотрудников полиции Российской Федерации и зарубежных государств // NB: Российское полицейское право. - 2013. - 1. - C. 65 - 83. DOI: 10.7256/23064218.2013.1.735. URL: http://www.e-notabene.ru/pm/article_735.html

5. Куракин А.В. Административно-правовые аспекты юридической ответственности в механизме противодействия коррупции в системе государственной службы Российской Федерации // NB: Административное право и практика администрирования. - 2013. - 7. - C. 137 - 157. DOI: 10.7256/23069945.2013.7.9954. URL: http://www.e-notabene.ru/al/article_9954.html

6. Куракин А.В. Международно-правовые источники административного права в сфере противодействия коррупции в системе государственной службы Российской Федерации // Административное и муниципальное право. - 2013. - 3. - C. 240 - 249. DOI: 10.7256/1999-2807.2013.03.7.

7. Куракин А.В., Ватель А.Ю., Тереньтьев Э.В. Административно-правовое регулирование этического поведения государственных гражданских служащих и обеспечение их надлежащего служебного поведения // Административное и муниципальное право. - 2012. - 5. - С. 9 - 17. 
8. Куракин А.В., Кулешов Г.Н. Государственная служба и информационные технологии // NB: Административное право и практика администрирования. - 2013. - 12. - C. 1 - 20. DOI: 10.7256/23069945.2013.12.10701. URL: http://www.e-notabene.ru/al/article_10701.html

9. Костенников М.В. Новая книга об административно правовом развитии профессиональной служебной деятельности / Комахин Б.Н. «Административно-правовые основы развития служебной деятельности в контексте политики модернизации». - Москва: ИПУ РАН. 2013. 474 с. // Административное и муниципальное право. - 2013. - 6. - C. 685 - 686. DOI: 10.7256/1999-2807.2013.06.14.

10. Трегубова Е.В., Марьян А.В., Кривоносов Д.А. Административно-правовое регулирование института правового запрета в системе государственной службы // Административное и муниципальное право. $-2010 .-8 .-$ С. $7-16$.

\section{References:}

1. Kostennikov M.V., Kurakin A.V. Aktual'nye problemy administra-tivnogo prava. - M., 2013.

2. Kurakin A.V. Predmet administrativno-pravovogo regulirovaniya v mekhanizme protivodeistviya korruptsii $v$ politsii. — Domodedovo: VIPK MVD Rossii, 2013.

3. Kurakin A.V.Mezhdunapodnoeiadministrativnoe pravo i protivodeistvie korruptsii v sistemegocudapctvennoi grazhdanskoi sluzhby // NB: Administrativnoe pravo i praktika administrirovaniya. - 2014. - 1. - C. 53 81. DOI: 10.7256/2306-9945.2014.1.11051. URL: http://www.e-notabene.ru/al/article_11051.html

4. Kurakin A.V., Kostennikov M.V.Administrativno-pravovoe protivodeistviekorruptsiiv sistemegosudarstvennoi sluzhby i v deyatel'nosti sotrudnikov politsii Rossiiskoi Federatsii i zarubezhnykh gosudarstv // NB: Rossiiskoe politseiskoe pravo. - 2013. - 1. - C. 65 - 83. DOI: 10.7256/2306-4218.2013.1.735. URL: http://www.enotabene.ru/pm/article_735.html

5. Kurakin A.V. Administrativno-pravovye aspekty yuridicheskoi otvetstvennosti v mekhanizme protivodeistviya korruptsii v sisteme gosudarstvennoi sluzhby Rossiiskoi Federatsii // NB: Administrativnoe pravo i praktika administrirovaniya. - 2013. - 7. - C. 137 - 157. DOI: 10.7256/2306-9945.2013.7.9954. URL: http:// www.e-notabene.ru/al/article_9954.html

6. Kurakin A.V. Mezhdunarodno-pravovye istochniki administrativnogo prava v sfere protivodeistviya korruptsii v sisteme gosudarstvennoi sluzhby Rossiiskoi Federatsii // Administrativnoe i munitsipal'noe pravo. — 2013. - 3. - C. 240 - 249. DOI: 10.7256/1999-2807.2013.03.7.

7. Kurakin A.V., Vatel' A.Yu., Teren't'ev E.V. Administrativno-pravovoe regulirovanie eticheskogo povedeniya gosudarstvennykh grazhdanskikh sluzhashchikh i obespechenie ikh nadlezhashchego sluzhebnogo povedeniya // Administrativnoe i munitsipal'noe pravo. - 2012. - 5. - C. 9 - 17.

8. Kurakin A.V., Kuleshov G.N. Gosudarstvennaya sluzhba i informatsionnye tekhnologii // NB: Administrativnoe pravo i praktika administrirovaniya. - 2013. - 12. - C. 1 - 20. DOI: 10.7256/2306-9945.2013.12.10701. URL: http://www.e-notabene.ru/al/article_10701.html

9. Kostennikov M.V. Novaya kniga ob administrativno pravovom razvitii professional'noi sluzhebnoi deyatel'nosti / Komakhin B.N. «Administrativno-pravovye osnovy razvitiya sluzhebnoi deyatel'nosti v kontekste politiki modernizatsii». — Moskva: IPU RAN. 2013. 474 s. // Administrativnoe i munitsipal'noe pravo. — 2013. - 6. - C. 685 - 686. DOI: 10.7256/1999-2807.2013.06.14.

10. Tregubova E.V., Mar'yan A.V., Krivonosov D.A. Administrativno-pravovoe regulirovanie instituta pravovogo zapreta v sisteme gosudarstvennoi sluzhby // Administrativnoe i munitsipal'noe pravo. - 2010. - 8. - C. $7-16$. 